\title{
OS DIREITOS DA MULHER NO MERCADO DE TRABALHO: da Discriminação de Gênero à Luta Pela Igualdade
}

\section{Dirceu Pereira Siqueira}

Pós-doutorado em Direito pela Faculdade de Direito da Universidade de Coimbra (Portugal), doutor e mestre em Direito Constitucional pela Instituição Toledo de Ensino (ITE/Bauru); especialista lato sensu em Direito Civil e Processual Civil pelo Centro Universitário de Rio Preto, pesquisador bolsista - Modalidade Produtividade em Pesquisa para Doutor (PPD) do Instituto Cesumar de Ciência, Tecnologia e Inovação (Iceti); professor-permanente do Programa de Mestrado em Direito do Centro Universitário Cesumar (UniCesumar) e nos cursos de Graduação em Direito da Universidade de Araraquara (Uniara), do Centro Universitário Unifafibe (Unifafibe) e do Centro Universitário da Fundação Educacional de Barretos (Unifeb). Advogado. dpsiqueira@uol.com.br

\section{Ana Julia Fernandes Samparo}

Mestranda em Direito pelo Centro Universitário de Maringá (UniCesumar). anajuliafs4@gmail.com

\section{Resumo}

Ao longo da história a mulher sempre foi submetida ao homem e vista à margem da sociedade pelo simples fato ser mulher. Tal condição sempre a acompanhou, sendo inegável a influência desta circunstância nas relações de trabalho, tendo como base as teorias que exploram a divisão sexual do trabalho, consequência do culturalismo no corpo social. 0 escopo do presente texto, portanto, parte da trajetória feminina na História, e analisa como 0 Direito atende à realidade e às necessidades da mulher, principalmente dentro do aspecto laboral, os efeitos da divisão sexual do trabalho, bem como a análise da efetividade e dever da atuação estatal no contexto desta problematização. Partiu-se do estudo da inserção feminina no mercado de trabalho à luta pela garantia dos direitos fundamentais da mulher neste ambiente. Concluiu-se assim apesar do decorrer do tempo, e das conquistas femininas advindas da luta constante das mulheres em busca da tão sonhada inserção e igualdade, a discriminação, a distinção e o preconceito ainda se fazem presentes em tempos modernos.

\section{Palavras-chave:}

Gênero. Mulher. Mercado de trabalho. Discriminação. Proteção. Igualdade.

\section{Revista}




\section{THE RIGHTS OF WOMEN IN THE LABOR MARKET:}

\section{From Gender Discrimination to Fight for Equality}

\section{Abstract}

Throughout the years, women had always been submitted to men and were seen to be at the margins of society for the simple fact of being a woman. Such condition had always accompanied them, whose circustance influence is undeniable in the workplace relations. On the basis of the theories which explore the gender division in the work environment, due to the culturalism in the social body, women have been many times deprived of their own freedom of professional choice, being also discriminated against in countless labor market related situations, not rarely having lower wages compared to their male perspective. However, this project's scope, based on women's history , mainly within their aspect of labour, the effects of the gender division at work, as well as the affective analysis and the duty of the governamental activily regarding this questioning The method used in this project was the deductive thinking, based on the study of women insertion into the labour market, also the fight for the guarantee of their basic human rights. In conclusion, despite the passing of time, and the women's accomplishments stemming from their constant battle in the pursuit of their long-overdue insertion and equality, discrimination, distinction, prejudice which still linger nowadays.

\section{Keywords:}

Gênero. Woman. Labor market. Discrimination. Protection. Equality.

Recebido em: 27/8/2017

Aceito em: 4/10/2017

\section{Sumário:}

1 Introdução. 2 Relações de gênero. 3 Divisão sexual do trabalho. 4 Dos direitos fundamentais e sua correlação com a discriminação laboral da trabalhadora. 5 A proteção do trabalho da mulher. 6 Medidas de combate à desigualdade de gênero. 7 Considerações finais. 8 Referências. 


\section{INTRODUÇÃO}

A desigualdade é compreendida como a ausência de proporção e equilíbrio, sinônimo de irregularidade, desproporção e até mesmo inferioridade. É penoso saber que em pleno século 21 e após várias e incansáveis lutas pela sua inserção no mercado de trabalho, as mulheres ainda sofrem com o preconceito.

Em recentes pesquisas realizadas pela Organização Internacional do Trabalho (OIT), nos dias atuais, considerando uma média mundial, as mulheres recebem o equivalente a $77 \%$ dos salários dos homens, logo, se nenhuma medida for tomada, a igualdade salarial entre gêneros somente será alcançada em 2086, ou seja, após 71 anos. ${ }^{1}$ Desta maneira, visando a averiguar as relaçóes de gênero durante o decorrer do tempo, faz-se necessário, primeiramente, compreender a concepçáo distinta que se possui de sexo e de gênero, visto que, normalmente, ambas as palavras são tratadas como sinônimas. Assim, enfatiza-se que o sexo faz referência apenas a questôes biológicas, enquanto gênero é interpretado como a construção da identidade de cada ser humano, a partir da influência cultural e das instituiçóes sociais.

Consequentemente, a partir desta diferenciação, ao longo da História, a mulher passou a ser vista em uma condição de inferioridade ao homem, devendo obediência a este por conta de seu sexo biológico. Apesar do grande desenvolvimento, no sentido da promoção da inserção da mulher na sociedade, e, por conseguinte, da incorporaçáo desta no mercado de trabalho, advindas das lutas dos movimentos feministas, a desigualdade salarial, a discriminação e a não proteção do labor da mulher ainda se fazem presentes.

Na busca do entendimento do motivo pelo qual se dá a discriminação de gênero, foram analisadas as três grandes teorias que versam sobre a origem das diferenças existentes entre homens e mulheres, as chamadas teoria universalista, teoria diferencialista, também denominada de substancialista, e a teoria queer, com a finalidade de compreender a divisão sexual do trabalho, a qual pode ser

${ }_{1}$ Mulheres só receberão o mesmo salário que os homens em 2086, diz OIT. Correio Braziliense, Brasília, 6 mar. 2015. Mundo. Disponível em: <http://www.correiobraziliense.com.br/app/noticia/ mundo/2015/03/06/interna_mundo,474329/mulheres-so-receberao-mesmo-salario-que-homens-em-2086-oit.shtml >. Acesso em: 17 jul. 2015. 
considerada uma tipologia de violência, a chamada violência simbólica, que tanto quanto a violência física deve ser combatida. Conjuntamente, foram apreciados os direitos fundamentais e os princípios trabalhistas, os quais são amplamente feridos quando não respeitada a devida proteção laboral da mulher, bem como a igualdade, seja para ingressar no próprio mercado, seja dentro deste, principalmente no que diz respeito ao salário.

Assim sendo, na busca de respostas e possíveis soluçôes a essas indagaçốes, serão apresentadas bibliografias de gênero, feministas, trabalhistas, filosóficas e sociológicas, afinal, o homem é fruto do meio no qual ele vive, e para mudar o corpo social faz-se imprescindível analisá-lo na tentativa de compreendê-lo.

\section{RELAÇÕES DE GÊNERO}

Com o objetivo de compreender a divisão sexual do trabalho, a história e as leis que protegem a mulher no âmbito trabalhista, é de suma importância distinguir o entendimento que se tem de gênero do que se possui quanto ao sexo biológico. ${ }^{2}$

Foi em 1972 que os sexólogos John Money e Anke Ehrhardt propagaram a concepção de distinção de sexo e gênero, visto que sexo estaria atrelado a atributos biológicos e gênero à identidade de cada ser humano. Simultaneamente, na década de 70 , a segunda geração feminista também faz referência ao discernimento entre sexo e gênero. ${ }^{3}$

Logo, gênero é compreendido como uma categorização pessoal e social dos indivíduos, com base na construção de sua identidade, portanto independe do sexo biológico.

2 JESUS, Jaqueline Gomes de. Orientaçôes sobre a população transgênero: conceitos e termos. Brasília: Autor, 2012. Disponível em: <https://www.sertao.ufg.br/up/16/o/ORIENTA\%C3\%87\%C3\%95ES_ SOBRE_IDENTIDADE_DE_G\%C3\%8ANERO_CONCEITOS_E_TERMOS_-_2\%C2\%AA_ Edi\%C3\%A7\%C3\%A3o.pdf?1355331649>. Acesso em: 25 jun. 2016. p. 24.

3 FAUSTO-STERLING, Anne. Dualismos em duelo. Cadernos Pagu, Campinas, n. 17-18, p. 9-79, 2002. Disponível em: <http://www.scielo.br/scielo.php?script=sci_arttext\&pid=S0104$-83332002000100002 \& \operatorname{lng}=e n \& n r m=$ iso $>$. Acesso em: 26 jun. 2016. 
Também deve ser levado em consideração o fato de que o patriarcalismo influenciou diversas doutrinas quanto à percepção de gênero. Nesse sentido, a concepção aristotélica argumentava que o feto era fruto do encontro do esperma com o mênstruo e a mulher seria apenas uma matéria passiva nesta relaçáo. Partindo desta premissa, Hipócrates acreditava que o ser humano era dividido em duas espécies: uma fraca, o feminino, e uma forte, o masculino. ${ }^{4}$

Visto dessa forma, "a perpetuação da espécie não acarreta a diferenciação sexual. Mesmo que esta seja assumida pelos seres existentes" . ${ }^{5}$ Criticando tal posição de Aristóteles, em 1990 Laqueur argumenta que:

Aristóteles não precisou de fatos da diferença sexual para apoiar sua proposição de que a mulher era um ser inferior ao homem; ela era consequência da verdade apriorística segundo o qual a causa material é inferior à causa eficiente. É claro que homens e mulheres eram identificados no cotidiano por suas características corporais, mas a asserção de que na geração o homem era a causa eficiente e a mulher a causa material não era, por princípio, fisicamente demonstrável; era em si mesma uma reafirmação do que significava ser masculino ou feminino. A natureza específica dos ovários ou do útero era, assim, apenas incidental na definição da diferença sexual. No século XVIII, isso já não era mais válido. O ventre, antes uma espécie de fato negativo, tornou-se o útero - um órgáo cujas fibras, nervos e sistema vascular, fornecia uma explicação e uma justificativa natural para o status social da mulher. ${ }^{6}$

${ }^{4}$ BEAUVOIR, Simone de. O segundo sexo: fatos e mitos. Tradução Sérgio Milliet. 4. ed. São Paulo: Difusăo Europeia do Livro, 1970. p. 30. V. 1.

5 BEAUVOIR, Simone de. O segundo sexo: fatos e mitos. Tradução Sérgio Milliet. 4. ed. São Paulo: Difusăo Europeia do Livro, 1970. p. 29. V. 1.

${ }^{6}$ LAQUEUR, 1990, p. 151 apud NICHOLSON, Linda. Interpretando o gênero. Tradução Luiz Felipe Guimarães Soares. Revista Estudos Feministas, Florianópolis, v. 8, n. 2, p. 21, 2000. Disponível em: <https://periodicos.ufsc.br/index.php/ref/article/view/11917>. Acesso em: 26 jun. 2016. 
Por outro lado, a teoria psicanalista sobre gênero, a qual possui como alguns expoentes Sartre e Freud, alega que tudo é um fenômeno sexual. Desta forma, é por meio da sexualidade que o sujeito consegue compreender qual o seu gênero e sua respectiva identidade. ${ }^{7}$

Concernente ao ponto de vista da teoria do materialismo histórico, a separação de gênero não pode ser vista unicamente por pontos da Biologia ou da Psicanálise, deve ser levada em consideração a História da humanidade, partindo do princípio de que "[...] a sociedade humana é uma anti-phisis: ela não sofre passivamente a presença da Natureza, ela retoma em mãos". ${ }^{8}$ É sob esta ótica que Engels defende a proposta de que o trabalho, como fator histórico, teria determinado o contraste de gênero, dividindo o masculino e o feminino pois, segundo ele, a propriedade privada teria feito o homem o senhor dos escravos e das mulheres, constituindo esta a grande derrota do sexo feminino. ${ }^{9}$

É impossível, todavia, falar de gênero separado do corpo, e, por conseguinte, do sexo biológico, visto que, conforme Linda Nicholson afirma, "sexo não pode ser independente de gênero, antes, sexo nesse sentido deve ser subsumido pelo gênero." ${ }^{10}$ É fundamental enxergar o ser humano em sua totalidade, um conjunto formado por corpo, sexo biológico, gênero e identidade de gênero, que nada mais é que o gênero com o qual determinado sujeito se identifica e pode ser diferente daquele atribuído quando de seu nascimento.

7 BEAUVOIR, Simone de. O segundo sexo: fatos e mitos. Tradução Sérgio Milliet. 4. ed. São Paulo: Difusão Europeia do Livro, 1970. p. 60. V. 1.

8 SANTO AGOSTINHO apud BEAUVOIR, Simone de. O segundo sexo: fatos e mitos. Tradução Sérgio Milliet. 4. ed. São Paulo: Difusão Europeia do Livro, 1970. p. 73. V. 1.

9 BEAUVOIR, Simone de. O segundo sexo: fatos e mitos. Tradução Sérgio Milliet. 4. ed. São Paulo: Difusẫo Europeia do Livro, 1970. V. 1.

${ }^{10}$ NICHOLSON, Linda. Interpretando o gênero. Tradução Luiz Felipe Guimarães Soares. Revista Estudos Feministas, Florianópolis, v. 8, n. 2, 2000. Disponível em: <https://periodicos.ufsc.br/index. php/ref/article/view/11917>. Acesso em: 26 jun. 2016. 
Por fim, é possível chegar-se à conclusão de que o gênero é um fato social que advém do papel exercido pelos indivíduos dentro da sociedade, levando-se em consideração o corpo físico. É por tal motivo que, para Simone de Beauvoir, “[...] não se nasce mulher, torna-se mulher". ${ }^{11}$

A pré-História tem como sinônimo 700 mil anos de História da humanidade. Sabe-se, por meio de estudos feitos por arqueólogos e historiadores, que nos períodos mencionados houve predominância do sistema matriarcal, haja vista a importância e primazia da maternidade, bem como a necessidade de povoamento. Apesar de a força física ser o principal fator divisório de funçóes, as mulheres ainda se apresentavam como líderes, tornando claro o sistema matriarcal, uma vez que esta liderança era advinda do seu grande papel como procriadora, sendo negociável a proteção por parte do sexo masculino. Cabe esclarecer que neste estágio o homem não conhecia seu papel na concepção.

Foi por meio da domesticação dos animais, haja vista a observância dos períodos de cios das fêmeas, bem como a prenhez e partos, que os homens descobriram sua incumbência imprescindível na concepção. A partir deste momento o poder que as mulheres possuíam foi se desvanecendo, e o sexo masculino tornando-se autoritário e opressor. Era o fim do sistema matriarcal e igualitário e o início do sistema patriarcal. Atualmente são quase irrisórias as sociedades matriarcais, com dados na Austrália, os chamados nagovisis, os minangkabaus, na Indonésia, os khasis do norte da Índia, e por fim os Ede, do Tibet. ${ }^{12}$

${ }^{11}$ BEAUVOIR, Simone de. O segundo sexo: fatos e mitos. Tradução Sérgio Milliet. 4. ed. São Paulo: Difusão Europeia do Livro, 1970. p. 9. V. 1.

${ }^{12}$ ROMANZOTI, Natasha. Sociedade em que as mulheres mandam podem nos ensinar muitas coisas. Disponível em: <http://hypescience.com/sociedades-em-que-as-mulheres-mandam/>. Acesso em: 2 ago. 2016. 
Nesse sentido, entende-se que o patriarcado é um meio de dominação das mulheres pelos homens por força do gênero, ${ }^{13}$ ou seja, "[...] trata-se de um sistema autoritário, cuja ausência de liberdade pessoal afeta ambos os sexos, de um lado as mulheres, as quais devem ser submissas e acatar ordens tidas como indubitáveis, e do outro os homens, que ficam restritos quanto aos modos de expressarem-se". ${ }^{14}$

Por sua vez, na Antiguidade oriental a mulher era considerada como uma propriedade masculina, não possuindo qualquer tipo de direitos, destacando-se que o patriarcalismo também se fez presente na sociedade grega, berço da civilização ocidental. ${ }^{15}$

Já durante a Idade Média a mulher, devido à ascensão do cristianismo, foi mais marginalizada, cumprindo estritamente o dever de obrigação e subordinação, primeiramente ao seu pai e posteriormente a seu marido, devendo seguir os princípios da: "castidade, humildade, silêncio e trabalho". ${ }^{16}$ Foi a partir da Idade Moderna, com o Renascimento, que as mulheres começaram a exigir sua liberdade e autonomia, na tentativa de ganhar seu espaço no meio social. ${ }^{17}$

Nessa época houve um início de paridade quanto às funçôes laborais tidas como masculinas e femininas, visto que algumas mulheres começaram a laborar como escrivãs, médicas e professoras, entretanto, por mais que trabalhassem de igual forma em relação aos homens, o valor de seu salário era inferior. ${ }^{18}$

13, SAFFIOTI, Heleith Iara Bongiovani. Gênero, patriarcado, violência. São Paulo: Fundação Perseu Abramo, 2004. p. 44.

${ }^{14}$ ROCHA, Patrícia. Mulheres sob todas as luzes: a emancipação feminina e os últimos dias do patriarcado. Belo Horizonte: Ed. Leitura, 2009. p. 10.

${ }^{15}$ ROCHA, Patrícia. Mulheres sob todas as luzes: a emancipação feminina e os últimos dias do patriarcado. Belo Horizonte: Ed. Leitura, 2009. p. 67.

${ }^{16}$ ROCHA, Patrícia. Mulheres sob todas as luzes: a emancipação feminina e os últimos dias do patriarcado. Belo Horizonte: Ed. Leitura, 2009. p. 83-84.

${ }^{17}$ ROCHA, Patrícia. Mulheres sob todas as luzes: a emancipação feminina e os últimos dias do patriarcado. Belo Horizonte: Ed. Leitura, 2009. p. 101.

${ }^{18}$ SULLEROT, Evelyne. História y sociologia de trabajo femenino. Tradução Bustamante Ortiz. Barcelona: Ediciones, 1970. p. 58. 
A Idade Contemporânea foi marcada pelas grandes revoluçôes burguesas, em especial a Revolução Francesa de 1789, na qual as mulheres participaram ativamente na luta pela igualdade, liberdade e fraternidade. Ao final do conflito, todavia, as mulheres especificadamente foram esquecidas quanto às suas particularidades e necessidade de proteção, no que tange à Declaração de Direitos do Homem e do Cidadão. Jean-Jacques Rousseau, grande filósofo iluminista que influenciou a Revolução Francesa, acreditava na impossibilidade de igualdade entre homem e mulher, sob o argumento de que esta é naturalmente inferior, e sua única função é servir ao homem. ${ }^{19}$

Ainda nos séculos 18 e 19 ocorreram Revoluçóes Industriais, que geraram grandes impactos no setor trabalhista. Em tal época houve uma grande exploração da mão de obra, com a feminina sendo utilizada em grande escala, especialmente por ser considerada mão de obra barata. Ressalta-se que inexistiam quaisquer normas de proteção ou que especificassem a jornada de trabalho. ${ }^{20}$

Na perspectiva de Amauri Mascaro Nascimento:

(...) o trabalho feminino foi aproveitado em larga escala, a ponto de ser preterida a mão de obra masculina. Os menores salários pagos à mulher constituíam a causa maior que determinava essa preferência pelo elemento feminino. O Estado, não intervindo nas relaçóes jurídicas de trabalho, permitia, com a sua omissão, toda sorte de exploraçôes. Nenhuma limitação da jornada de trabalho, idênticas exigências dos empregadores quanto às mulheres e homens, indistintamente, insensibilidade diante da maternidade e dos problemas que pode acarretar à mulher, quer quanto às condiçóes pessoais, quer quanto às responsabilidades de amamentação e cuidados dos filhos em idade de amamentação $[. ..] .^{21}$

\footnotetext{
${ }^{19}$ ROCHA, Patrícia. Mulheres sob todas as luzes: a emancipaçáo feminina e os últimos dias do patriarcado. Belo Horizonte: Ed. Leitura, 2009. p. 125.

${ }^{20}$ NASCIMENTO, Amauri Mascaro. Curso de Direito do Trabalho: história e teoria geral do Direito do Trabalho, relaçôes individuais e coletivas do trabalho. 26. ed. São Paulo: Saraiva, 2011. p. 908.

${ }^{21}$ NASCIMENTO, Amauri Mascaro. Curso de Direito do Trabalho: história e teoria geral do Direito do Trabalho, relaçóes individuais e coletivas do trabalho. 26. ed. São Paulo: Saraiva, 2011. p. 909.
} 
Diante das grandes violaçôes que as mulheres sofriam no ambiente laboral, as primeiras leis trabalhistas voltaram-se para a sua proteção. Nos anos de 1842 e 1844 a Inglaterra já proibia, nesta ordem, o labor da mulher em locais subterrâneos e limitava sua jornada. Em 1848 a França produziu várias leis de proteção ao trabalho da mulher, e 43 anos depois, em 1891, a Alemanha criou o Código Industrial, visando a fixar normas de proteção trabalhistas. ${ }^{22}$

Salienta-se a inegável influência da Organização Internacional do Trabalho (OIT) sobre a CLT brasileira, ${ }^{23}$ visto que as Convençôes n. 3, 103 e 183 deste órgão, datadas de 1919, 1966 e 1988, respectivamente, já regulamentavam o trabalho da mulher em estado gravídico-puerperal, além das Convençóes n. 4, 41 e 89, de 1919, 1934 e 1938, que estipulavam o regime de horas extras e com pesos, bem como as de n. 110 e 111, que estipulavam o salário igual, independente de sexo e gênero. ${ }^{24}$

Por fim, cabe mencionar que com a globalização e o surgimento da Internet, no século 20, apesar de ainda existir as mais diversas formas de discriminação em razão da diferença de gênero e sexo, as interaçóes e discussóes quanto às tradiçóes de gêneros e os ideais de igualdade, dignidade, liberdade e felicidade para a mulher e qualquer ser humano, defendidas por vários movimentos feministas, vêm trazendo desenvolvimento e um grande impacto positivo na sociedade. ${ }^{25}$ Antes de adentrar aos movimentos sociais que objetivam a igualdade de gênero, que envolvem sobretudo as relaçôes de trabalho, faz-se fundamental compreender o feminismo e suas ondas, bem como a conexão de poder, dominação e liberdade mitigada que sofreram e sofrem as mulheres.

${ }^{22}$ NASCIMENTO, Amauri Mascaro. Curso de Direito do Trabalho: história e teoria geral do Direito do Trabalho, relaçóes individuais e coletivas do trabalho. 26. ed. Sáo Paulo: Saraiva, 2011. p. 910.

${ }^{23}$ BARROS, Alice Monteiro de. Curso de Direito do Trabalho. 7. ed. São Paulo: LTr. 2011. p. 855.

${ }^{24}$ ORGANIZAÇÃO INTERNACIONAL DO TRABALHO (OIT). Promovendo o trabalho decente. Disponível em: <http://www.oitbrasil.org.br/convention>. Acesso em: 25 jun. 2016.

${ }^{25}$ STEARN, Peter N. História das relaçôes de gênero. 2. ed. Traduçáo Mirna Pinsky. São Paulo: Contexto, 2015. p. 23. 
O movimento feminista, historicamente, teve início na Europa, principalmente na França e na Inglaterra. A raiz de todas as correntes feministas advém da Revolução Francesa, compartilhando dos ideais de liberdade, igualdade e fraternidade, em suma, a máxima da justiça.

A primeira onda feminista nasceu com a Revolução Francesa até a Primeira Guerra Mundial, adquirindo força com o movimento sufragista, a chamada luta por cidadania. Salienta-se que o início do movimento feminista tem ligação direta com a divisão sexual do trabalho, haja vista a Revolução Industrial do século 18 , quando a mulher começou a laborar nas indústrias. ${ }^{26}$

O feminismo do século 18 é dividido em duas grandes vertentes, a liberal e a marxista. A primeira acreditava que a situação desigual da mulher era advinda do comportamento irracional da sociedade. Segundo o feminismo liberal a capacidade de uma pessoa realizar uma determinada atividade advinha de um conjunto de fatores, como educação e socialização, não da natureza biológica, ou seja, a "a causa da subordinação feminina estaria assentada nos preconceitos e estereótipos acerca das mulheres, e o espaço maior de manifestação desta dominação seria a própria vida pública". ${ }^{27}$

De outra banda, o feminismo marxista acreditava que as mulheres sofriam uma opressão dupla, seja por parte do Estado capitalista, naturalmente opressor, seja pela sociedade como um todo, no que tange à discriminaçáo laborativa. ${ }^{28}$ Desse modo, a hostil distinção da mulher só seria resolvida com o fim da propriedade privada, uma vez que com sua aboliçẫo haveria uma mudança da divisão, ou melhor, não haveria uma segregação de tarefas entre homens e mulheres.

${ }^{26}$ BRUSCHINI, Maria Cristina A.; ROSEMBERG, Fúlvia. A mulher e o trabalho. In: BRUSCHINI, Maria Cristina A; ROSEMBERG, Fúlvia. (Org.). Trabalhadoras do Brasil. São Paulo: Brasiliense; Fundação Carlos Chagas, 1982. p. 10.

${ }^{27}$ RABENHORST, Eduardo Ramalho. Feminismo e Direito. In: Revista do Núcleo de Estudos e Pesquisas em Gênero e Direito, João Pessoa: UFPB, v. 1, n. 1, 2010, nota 1.

${ }^{28}$ DAHL, Tove Stang. O Direito das mulheres: uma introduçáo à teoria do direito feminista. Lisboa: Fundação Calouste Gulbenkian, 1993. p. 14. 
A segunda onda do feminismo aparece nos Estados Unidos, em meados de 1960, cuja discussáo dominante era quanto à motivaçáo e causa das injustiças por causa do gênero e a busca de soluçóes para tais inquietaçôes. ${ }^{29}$ Nessa época surge, além das vertentes já mencionadas, o feminismo igualitário, o qual entendia que a desigualdade de gênero era advinda do sexismo, e o feminismo radical, que apontava o patriarcado como a origem de toda opressão feminina. ${ }^{30}$

Por sua vez, a terceira onda feminista, conhecida também como pós-feminista, propóe novas discussóes acerca dos direitos humanos e igualdade, incluindo em seus debates questóes que envolvem a raça, etnias, religiáo, classe e sexualidade, abrangendo assim a luta das mais diversas pessoas. ${ }^{31}$

Em relação ao Dia Internacional da Mulher, fruto da luta feminina por melhores condiçóes de vida e trabalho, comemorado todo o dia 8 de março, muitos acreditam que a data é devida ao incêndio em Triangle Shirtwaist Company, ocorrido em Nova York, todavia na realidade a escolha do dia comemorativo advém das manifestaçôes ocorridas na Rússia em 8 de março de 1917, em que as mulheres saíram às ruas lutando contra a escassez de alimentos, devido à Revoluçáo Russa, e a volta de seus maridos da guerra. ${ }^{32}$

A tragédia ocorrida em 25 de março de 1911, na fábrica têxtil Triangle Shirtwaist Company, com toda a certeza influenciou a movimentaçáo feminina ocorrida em 1917, bem como continua influenciando a luta da mulher por igualdade e condiçôes de trabalho dignas a qualquer ser humano. Outro movimento interessante quanto ao empenho pela liberdade da mulher foi o Bra-Burning ou

${ }^{29}$ DAHL, Tove Stang. O Direito das mulheres: uma introdução à teoria do direito feminista. Lisboa: Fundação Calouste Gulbenkian, 1993. p. 13.

${ }^{30}$ LUCENA, Mariana Barrêto Nóbrega de. Os debates do movimento feminista: do movimento sufragista ao feminismo multicultural. Disponível em: <http://www.ufpb.br/evento/lti/ocs/index. php/17redor/17redor/paper/view/100/49>. p. 6. Acesso em: 24 maio 2016.

${ }^{31}$ LUCENA, Mariana Barrêto Nóbrega de. Os debates do movimento feminista: do movimento sufragista ao feminismo multicultural. Disponível em: <http://www.ufpb.br/evento/lti/ocs/index. php/17redor/17redor/paper/view/100/49>. p. 8. Acesso em: 24 maio 2016.

32 CARNEIRO, Adriana Jacob. Gênero e mídia: a cobertura do Dia Internacional da Mulher. 2011. 200 f. Dissertação (Mestrado) - Universidade Federal da Bahia, Faculdade de Comunicação, Salvador, 2011. Disponível em: <https://repositorio.ufba.br/ri/bitstream/ri/8679/1/Adriana\%20Jacob\%20 Carneiro.pdf>. p. 13. Acesso em: 25 jun. 2016. 
A Queima dos Sutiãs, do Women's Liberation Movement (WLM), ato que reuniu cerca 400 protestantes com a intenção de atear fogo em acessórios femininos, como sutiâs e espartilhos, visando a combater a dura imposição de regras de beleza e de comportamentos padrões e machistas às mulheres, ensejou grande reflexão da questáo do gênero feminino em todo o mundo. ${ }^{33}$

\section{DIVISÃO SEXUAL DO TRABALHO}

Influenciada pelo sistema patriarcal, a divisão sexual do trabalho consiste em atribuiçốes de atividades aos homens e mulheres devido ao seu sexo biológico, bem como aos culturalismos. Desse modo, nota-se que até nos tempos modernos ainda existe a nomeação de funçóes tidas como exclusivamente femininas, qual seja, em sua grande maioria, a atividade doméstica. Hodiernamente há três grandes teorias que versam sobre a origem das diferenças existentes entre homens e mulheres, as chamadas teoria universalista, teoria diferencialista, também denominada de substancialista, e a teoria queer.

A teoria universalista, que tem como principal expoente Simone de Beauvoir, parte da ideia de que todos os indivíduos são iguais, não sendo levadas em conta características vistas como secundárias, como sexo, raça ou língua. ${ }^{34}$ Seus seguidores acreditam que, além das distinçôes biológicas e sexuais entre homens e mulheres, todas as pessoas possuem diferenças advindas do meio social, conforme as crenças culturais do meio em que estáo inseridas. ${ }^{35}$

${ }^{33}$ CAVALCANTI, Christiane Villela. A moda de luxo e a mulher em uma capital brasileira. Dissertação (Mestrado) - Programa de Pós-Graduação em Administração, Pontifícia Universidade Católica de Minas Gerais, Belo Horizonte, 2013. Disponível em: <http://www.biblioteca.pucminas.br/teses/ Administracao_CavalcantiCV_1.pdf>. Acesso em: 5 fev. 2016.

${ }^{34}$ THOME, Candy Florencio. O princípio da igualdade de gênero e a participação das mulheres nas organizaçōes sindicais de trabalhadores. São Paulo: LTr, 2012. p. 115.

${ }^{35}$ HIRATA, Helena; SEGNINI, Liliana (Org.). Organização, trabalho e gênero. São Paulo: Senac São Paulo, 2007. p. 110. 
Por sua vez, os teóricos diferencialistas defendem a tese de que os homens e as mulheres são divergentes por natureza, todavia, apesar não argumentarem a favor de uma hierarquizaçáo entre os sexos, para eles a igualdade entre estes seria impossível, devido às experiências advindas da paternidade e maternidade. Noutra perspectiva, a teoria queer afirma que o sujeito não possui uma identidade fixa, de modo que estará sempre predisposto a alteraçôes externas a fim de construir o entendimento que tem de si mesmo. ${ }^{36}$

Estas teorias são essenciais para compreender o enquadramento das mulheres no âmbito familiar, como também no mercado de trabalho. É a partir de tais perspectivas que surge em 1970, na França, com a ascensão dos movimentos feministas, o chamado estudo da divisão sexual do trabalho. ${ }^{37}$

A divisão sexual do trabalho parte de dois princípios, o da separação e da hierarquia. $\mathrm{O}$ primeiro reconhece a existência de trabalhos tidos como especificamente femininos e outros como masculinos; por sua vez, o segundo admite a superioridade do homem em qualquer trabalho. ${ }^{38}$ Conclui-se que, em ambos, não há uma liberdade de escolha quanto às funçóes a serem exercidas pelos sexos, além de corroborar com a existência da dominação masculina sobre as mulheres. Partindo de uma visão sociológica, Weber define que a dominação que os homens exercem sobre as mulheres é fruto do culturalismo; assim, o sociólogo acredita que esta dominação está inserida na dominação tradicional. ${ }^{39}$

36 THOME, Candy Florencio. O princípio da igualdade de gênero e a participação das mulheres nas organizaçôes sindicais de trabalhadores. São Paulo: LTr, 2012. p. 115.

${ }^{37}$ KERGOAT, Danièle. Divisão sexual do trabalho e relações sociais de sexo. Tradução Miriam Nobre. ago. 2003. Disponível em: <http://poligen.polignu.org/sites/poligen.polignu.org/files/adivisaosexualdotrabalho_0.pdf>. Acesso em: 28 jun. 2016. p. 1.

${ }^{38}$ THOME, Candy Florencio. O princípio da igualdade de gênero e a participação das mulheres nas organizações sindicais de trabalhadores. São Paulo: LTr, 2012. p. 118.

${ }^{39}$ WEBER, Max. Economia e sociedade: fundamentos da sociologia compreensiva. Brasília: UnB, 2000. p. 33. 
Desta maneira, com a divisão sexual do trabalho imputam-se às mulheres as atividades tidas como domésticas e aos homens, o que se define como produtivas. ${ }^{40}$ Assim, a partir do momento da existência de imputação de certos trabalhos às mulheres, configura-se um dos meios em que se externa a violência simbólica, a qual é instituída

a violência simbólica institui-se por meio da adesáo que o dominado náo pode deixar de conceder ao dominador (logo à dominação), uma vez que ele não dispóe para pensá-lo ou pensar a si próprio, ou melhor, para pensar sua relação com ele, senão de instrumentos de conhecimento que ambos têm em comum e que, não sendo senão a forma incorporada da relação de dominação, mostram essa relação como natural: ou, em outros termos, que os esquemas que ele mobiliza para se perceber e se avaliar o dominador são o produto da incorporaçáo de classificaçóes, assim naturalizadas, das quais o seu ser social é produto. ${ }^{41}$

Desse modo, a divisão sexual do trabalho é vista como uma tipologia de violência e encontra-se "no âmago do poder que os homens exercem sobre as mulheres". ${ }^{42}$ Em tempos modernos e após tantas lutas para ingressar e se manterem no mercado de trabalho, as mulheres ainda sofrem inúmeros preconceitos, seja pela mais pura e injustificável discriminação, seja pela notória e inconsistente preferência que muitos empregadores possuem de contratar homens, diante da variedade de normas de proteção que existem visando à proteção do trabalho da mulher.

Salienta-se que estas normas são imprescindíveis, além de serem um reflexo da sociedade patriarcal, haja vista a cultura do machismo ser inerente no meio social, representam uma conquista do trabalho feminino, pois visam à inserção deste corpo social no âmbito trabalhista. O fim das normas de proteção do labor feminino representaria, além de um contrassenso, um retrocesso, posto que a grande

\footnotetext{
${ }^{40}$ HIRATA, Helena; SEGNINI, Liliana (Org.). Organização, trabalho e gênero. São Paulo: Senac São Paulo, 2007. p. 113.

${ }^{41}$ BOURDIEU, Pierre. A dominação masculina. Trad. Maria Helena Kuhner. Rio de Janeiro: Bertrand Brasil, 1999. p. 42.

${ }^{42}$ HIRATA, Helena; SEGNINI, Liliana (Org.) Organização, trabalho e gênero. São Paulo: Senac São Paulo, 2007. p. 114.
} 
maioria das mulheres seria obrigada a permanecer dentro de seus lares, objetivando a sua manutenção, não conseguindo nem ao menos ingressar no mercado de trabalho. Recentemente, a Organização Internacional do Trabalho (OIT) divulgou uma pesquisa, realizada em escala mundial, constatando que as mulheres recebem apenas $77 \%$ do valor salarial que os homens recebem, quando realizam o mesmo labor e em iguais condiçóes. Salienta-se que se nada for feito, a estimativa é que a paridade salarial entre os gêneros somente será alcançada em $2086 .{ }^{43}$

Analisando dados nacionais, o Brasil não foge do padrão, uma vez que, infelizmente, segundo os dados mais recentes, demonstrados pelo Fórum Econômico Mundial, em 2014, o Brasil caiu no ranking de desigualdade de gêneros, ocupando o $82^{\circ}$ lugar, ficando atrás de alguns vizinhos sul-americanos, como Argentina, Peru e Chile, os quais ocupam as $31^{\mathrm{a}}$, $45^{\mathrm{a}}$ e $66^{\mathrm{a}}$ posiçóes, respectivamente. ${ }^{44}$

Um dos fatores dessa situação com certeza advém do preconceito em relação à inserção da mulher no âmbito laboral, o que configura uma violência simbólica, como também um reflexo da divisão sexual do trabalho, visto que ainda existe a máxima de que lugar de mulher é "pilotando um fogáo". Sob este aspecto, o Ibope Inteligência realizou uma pesquisa para a Confederação Nacional da Indústria, a qual demonstra, conforme dados estratégicos no ano de 2016, que $84 \%$ dos homens estão empregados, enquanto entre as mulheres esse percentual é de $61 \%$.

${ }^{43}$ CORREIO BRAZILIENSE. Mulheres só receberão o mesmo salário que homens em 2086, diz OIT. Brasília, 6 mar. 2015. Disponível em: <http://www.correiobraziliense.com.br/app/noticia/ mundo/2015/03/06/interna_mundo,474329/mulheres-so-receberao-mesmo-salario-que-homens-em-2086-oit.shtml>. Acesso em: 17 jul. 2015.

${ }^{44}$ BRASIL. Observatório Brasil da igualdade de Gênero. Brasil cai para $82^{\circ} \mathrm{em}$ desigualdade de gênero, aponta relatório. Disponível em: $<$ http://www.observatoriodegenero.gov.br/menu/noticias/brasil-cai-para-82o-em-desigualdade-de-genero-aponta-relatorio>. Acesso em: 17 jul. 2015. 
Gráfico 1 - Brasileiros que estão trabalhando, exceto aposentados.

Percentual de respostas por gênero

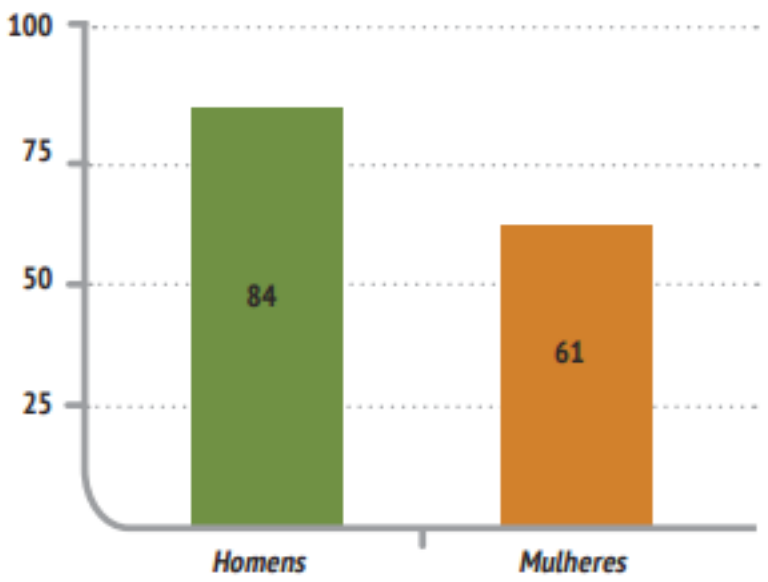

Fonte: CONFEDERAÇÃO..., 2016.

Em março de 2016, o Instituto de Pesquisa Econômica Aplicada (Ipea) divulgou uma pesquisa realizada entre os anos de 2004 e 2014, cujo foco era a análise da relação da mulher com o trabalho. O estudo revelou que naquele período houve um crescimento da renda salarial do trabalho para todos os indivíduos. Esse crescimento foi superior para as mulheres, cerca de $60 \%$, contra $44 \%$ dos homens. Logo, pode-se afirmar que houve uma reduçáo da desigualdade salarial feminina e masculina nos últimos anos.

Apesar, no entanto, de ter havido uma aproximação salarial, as mulheres continuam recebendo salários menores do que os homens, e esta disparidade aumenta em relação às mulheres negras.

Em escala mundial, haja vista o relatório "Mulheres no Trabalho: tendências de 2016", realizado pela Organizaçáo das Naçôes Unidas (ONU), o qual avaliou dados de até 178 países, concluiu que a desigualdade entre homens e mulheres 
persiste, uma vez que as mulheres continuam laborando por mais tempo que os homens, seja em trabalho remunerado ou não, e ganhando um valor menor do que o sexo masculino. ${ }^{45}$

Por fim, a pesquisa realizada pelo CNI, a segunda principal causa em média de as mulheres terem abandonado o último emprego foi para tomar conta de filhos e parentes, o que sugere que, geralmente, não há uma divisão de tarefas entre o casal no âmbito familiar, cabendo exclusivamente à mulher cuidar dos afazeres domésticos do lar.

Os efeitos da divisão sexual do trabalho geram graves consequências, uma delas a discriminação, ou seja, um tratamento diferenciado, decorrente do sexo biológico. Sabe-se que o conceito de discriminação é tido como neutro, uma vez que pode gerar efeitos positivos, como no caso de açóes afirmativas visando a uma proteção especial àqueles tidos vulneráveis, como também negativas, a partir do momento que institui dominações de um grupo social sobre outro. ${ }^{46}$

Assim, os efeitos da discriminação da mulher, decorrentes do sexo no ambiente laboral, dar-se-á de forma horizontal, quando são distribuídas atividades de maneira desigual entre homens e mulheres, considerando apenas fatores biológicos. Normalmente as mulheres são consideradas aptas a executar atividades manuais e de forma repetitiva, o que acaba por gerar degradação a sua saúde, visto que várias mulheres apresentam sintomas de Lesão por Esforço Repetitivo (LER/Dort) ou depressão em decorrência desse trabalho. ${ }^{47}$

Por sua vez, a discriminação vertical, também chamada de "teto de cristal" ou glass ceiling, refere-se à existência de uma quantidade reduzida de mulheres em cargos de decisão, bem como de menor remuneração. Além disso, a divisão

45 ORGANIZAÇÃO INTERNACIONAL DO TRABALHO (OIT). Desigualdades e gênero continuam grandes no mercado de trabalho global. Disponível em: <http://www.ilo.org/brasilia/noticias/ wcms_458115/lang--pt/index.htm>. Acesso em: 14 jul. 2016.

${ }^{46}$ DAHL, Tove Stang. O Direito das mulheres: uma introdução à teoria do direito feminista. Lisboa: Fundação Calouste Gulbenkian, 1993. p. 41.

${ }^{47}$ THOME, Candy Florencio. O princípio da igualdade de gênero e a participação das mulheres nas organizaçōes sindicais de trabalhadores. São Paulo: LTr, 2012. p. 132. 
do trabalho em virtude do gênero também é perceptível diante das desigualdades salariais, posto que na maioria dos países as mulheres são vítimas da não efetivação do princípio da igualdade diante de funçóes e produtividade iguais. ${ }^{48}$

\section{DOS DIREITOS FUNDAMENTAIS E SUA CORRELAÇÃO COM A DISCRIMINAÇÃO LABORAL DA OBREIRA}

Quando se declara que determinado direito é fundamental, é possível compreender que este direito é algo "que serve de fundamento ou de alicerce, que serve de base, importante, essencial, necessário". ${ }^{49}$ Conforme Uadi Lammêgo Bulos, direitos fundamentais são:

O conjunto de normas, princípios, prerrogativas, deveres e institutos, inerentes à sabedoria popular, que garantem a convivência pacífica, digna, livre e igualitária, independentemente de credo, raça, origem, cor, condição econômica ou status social. Sem os direitos fundamentais, o homem não vive, náo convive e, em alguns casos, não sobrevive. ${ }^{50}$

Sob tal concepção, todo o ser humano, inclusive as mulheres, possuem o direito de serem tratadas com igualdade e dignidade em qualquer ambiente, principalmente no meio laboral. Como já demonstrado, ainda existe discriminação em virtude da diferença de sexo. Ademais, possui a mulher o direito à liberdade laborativa, e por consequência, a oportunidade de buscar a felicidade em todos os meios, direitos estes que ao longo da História foram suprimidos pela imposição do sistema patriarcal, que se fundamenta na ideia de superioridade do homem.

48 SANTOS, Boaventura de Sousa. Pela mão de Alice: o social e o político na pós-modernidade. 10. ed. São Paulo: Cortez, 2005. p. 304.

${ }^{49}$ FUNDAMENTAL. In: Dicionário Michaelis. Disponível em: <http: http://michaelis.uol.com.br/ moderno/portugues/index.php?lingua=portugues-portugues\&palavra=fundamental $>$. Acesso em: 27 mar. 2016.

${ }^{50}$ BULOS, Uadi Lammêgo. Curso de Direito Constitucional. 8. ed. rev. e atual. São Paulo: Saraiva, 2014. p. 925 . 
O conceito que se tem de igualdade, contudo, não é homogêneo. Há aqueles que defendem a corrente nominalista, que acreditam que a desigualdade é intrínseca ao universo, de modo que o ser humano, ao nascer em uma condição de desigualdade, tal fator o acompanhará por toda a vida. De outra banda, os idealistas defendem a igualdade absoluta, tendo como um dos principais expoentes Rousseau, o qual reconhecia duas espécies de desigualdade, a natural, que consiste na diferença físico-biológica, como idade e sexo biológico, e na desigualdade moral, originada de detrimentos sociais, como alguns seres humanos mais ricos e outros menos. ${ }^{51}$

Com base nesta perspectiva, Aristóteles vinculou seu conceito de igualdade com o de justiça, fazendo nascer a famosa frase "Tratar de maneira igual os iguais e de maneira desigual os desiguais”. Robert Alexy explica que é crucial a existência de um motivo que justifique esta diferenciação, ou seja, trata-se de um problema de valoração, logo:

A necessidade de se fornecer uma razão suficiente que justifique a admissibilidade de uma diferenciação significa que, se uma tal razão não existe, é obrigatório um tratamento igual. Essa idéia pode ser expressa por meio do seguinte enunciado que é um refinamento da concepção fraca do enunciado geral de igualdade, a que aqui se deu preferência: Se não houver uma razão suficiente para a permissibilidade de um tratamento desigual, entâo, o tratamento igual é obrigatório. ${ }^{52}$

Convém esclarecer que o princípio da igualdade não se confunde com o da não discriminação, e muitos autores acreditam que aquele é espécie e este gênero, todavia, principalmente ao que respeita ao meio trabalhista, o princípio da igualdade atua verticalmente, uma vez que objetiva primordialmente reduzir a diferença salarial com base em fatores unicamente biológicos, e o da não discriminação opera horizontalmente, posto que visa a evitar açóes que prejudiquem trabalhadores mais vulneráveis. ${ }^{53}$

${ }^{51}$ SILVA, José Afonso da. Curso de direito constitucional positivo. 36. ed. São Paulo: Malheiros, 2013. p. 214.

52 ALEXY, Robert. Teoria dos Direitos Fundamentais. Virgílio Afonso da Silva (Trad.). 2. ed. São Paulo: Malheiros, 2008. p. 408.

${ }^{53}$ URIARTE, Oscar Ermida. Prefácio. In: LIMA, Firmindo Alves. Teoria da discriminação nas relaçôes de trabalho. Rio de Janeiro: Elsevier, 2011. p. 15. 
Nas normas que preconizam e protegem os labores exercidos pelas mulheres, é levada em consideração a igualdade material, ou seja, a realidade dos fatos, a existência de um mundo em que ainda há discriminação e diferença salarial para as mesmas atividades, fazendo uma análise comparativa entre os sexos. Trata-se, portanto, de uma questáo de justiça, dado que "o princípio de igualdade formal arriscar-se-ia, de fato, a permanecer (ao menos em parte) uma pura afirmação teórica, se não fosse integrado pelo de igualdade substancial" ${ }^{54}$

É a partir desta perspectiva que nasce o chamado princípio da igualdade de gênero, apreciando as necessidades e a devida proteção da mulher, com fundamento na dignidade da pessoa humana, bem como em respeito a sua vulnerabilidade específica. ${ }^{55}$

Paulo Roberto de Oliveira pondera que existem três diferenciaçóes que justificam a dessemelhança em relaçáo ao tratamento constitucional e em demais normas em relação à mulher: as questôes físicas, o contexto histórico e o liame social..$^{56}$

A atual situação da mulher e os direitos quanto à sua proteção, seja no âmbito laboral, seja em qualquer outro meio, estão nitidamente ligados ao Princípio da Dignidade da Pessoa Humana. Desta maneira, esclarece-se que o conceito de dignidade por mais flutuante e divergente que seja em suas interpretaçóes, parte de um ponto em comum: aquilo que é justo. Assim,

a ordem social e o seu progresso devem, pois, reverter sempre em bem das pessoas, já que a ordem das coisas deve estar subordinada à ordem das pessoas e não ao contrário [...]. Essa ordem, fundada na verdade, construída sobre a justiça e vivificada pelo amor, deve ser cada vez mais desenvolvida e, na liberdade, deve encontrar um equilíbrio cada vez mais humano. ${ }^{57}$

\footnotetext{
${ }^{54}$ MARTINES, Temistocle. Diritto costituzionale. 11. ed. Milano: Giuffrè, 2005. p. 527. Levar todos para ref.

${ }_{55}^{5}$ PIOVESAN, Flávia; SARMENTO, Daniel. Igualdade, diferença e direitos humanos. Rio de Janeiro: Lumen Juris, 2008, p.138.

56 LIMA, Paulo Roberto de Oliveira. Isonomia entre os sexos no Sistema Jurídico Nacional. São Paulo: Revista dos Tribunais, 1993. p. 27-29.

${ }^{57}$ DIAS, José Francisco de Assis. Direitos humanos: fundamentação onto-teleológica dos direitos humanos. Maringá: Unicorpore, 2005. p. 55.
} 
Indubitavelmente, a dignidade é um valor moral inerente a cada ser humano, o qual foi consagrado como um direito fundamental na Constituição Cidadã de 1988. Conforme Alexandre de Moraes, o princípio da dignidade possui dois julgamentos: primeiro como um direito protetivo, seja frente ao Estado, seja frente às demais pessoas, e em segundo como uma visão igualitária em relação a todos os indivíduos. ${ }^{58} \mathrm{~A}$ partir da compreensão da duplicidade do Direito Fundamental à Dignidade, agora quanto sua dimensão positiva e negativa, explica Pérez Luño:

A dignidade humana consiste náo apenas na garantia negativa de que a pessoa não será alvo de ofensas e humilhaçôes mas também agrega a afirmação positiva do pleno desenvolvimento da personalidade de cada indivíduo. O pleno desenvolvimento da personalidade pressupóe, por sua vez, de um lado, o reconhecimento da total autodisponibilidade, sem interferências ou impedimentos externos, das possíveis atuaçóes próprias de cada homem; de outro, a autodeterminação (Selbstbestimmung des Menschen) que surge da livre projeçáo histórica da razão humana, antes que de uma predeterminaçáo dada pela natureza. ${ }^{59}$

No aspecto do Direito do Trabalho, por muito tempo o salário da mulher foi visto como um valor de complementação para a renda familiar, razão pela qual se justificaria menor remuneração recebida do que pelo homem.

Este entendimento entra em total contrassenso com o defendido pela Declaração Universal dos Direitos Humanos, posto que: "Todo o homem que trabalha tem direito a uma remuneração justa e satisfatória, que lhe assegure, assim como à sua família, uma existência compatível com a dignidade humana, e a que se acrescentarão, se necessário, outros meios de proteção social”. Além de ferir o direito à igualdade, revela-se um grande atentado à dignidade da pessoa humana, visto que é garantia de qualquer pessoa laborar em um local sem discriminação e dignidade, inclusive no que cabe à isonomia salarial.

Por fim, reconhecendo que a divisão sexual do trabalho é uma espécie de violência simbólica, constata-se um atentado aos direitos humanos quando esta é praticada, visto que "os direitos das mulheres e das meninas são parte integrante,

\footnotetext{
${ }^{58}$ MORAES, Alexandre de. Direito constitucional. 11. ed. São Paulo: Atlas, 2002. p. 48.

${ }^{59}$ TAVARES, André Ramos. Curso de direito constitucional. 11. ed. Sáo Paulo: Saraiva, 2013. p. 442.
} 
indivisível e inalienável dos direitos humanos e que a violência de gênero é incompatível com a dignidade e o valor da pessoa humana". ${ }^{60}$ Logo, a proteção do labor da mulher tem em suma essencialidade a dignidade, e se justifica "em razão de ainda existir nos dias atuais resquícios da cultura baseada no sistema patriarcal segundo o qual a mulher [...] encontra-se em uma relação de inferioridade perante o homem". ${ }^{61}$

Sabe-se que a liberdade é uma conquista que se ampliou com o decorrer do tempo, pode-se até mesmo afirmar que seu conceito foi alterado conforme os anos, isto porque "depende do poder do homem sobre a natureza, a sociedade, e sobre si mesmo em cada momento histórico". ${ }^{62}$ Desse modo, é possível afirmar que existem seis aspectos de liberdade: a liberdade da pessoa física, que diz respeito à liberdade de ir e vir; liberdade de pensamento, a qual se traduz no livre-arbítrio, seja em questôes de escolha religiosa, até mesmo de opiniôes; liberdade de expressão coletiva, ou seja, a possibilidade de realizar reuniōes e associaçôes; liberdade de ação profissional, entendida como a livre escolha e exercício profissional; liberdade de conteúdo econômico e social, compreendido como livre iniciativa de mercado; liberdade de autonomia, de ensino e de trabalho. ${ }^{63}$

Para José Afonso da Silva, "liberdade consiste na possibilidade de coordenação consciente dos meios necessários à realização da felicidade pessoal”. ${ }^{64}$ Assim sendo, a direito à liberdade está intimamente ligado ao direito à felicidade, busca essencial do ser humano, que nas palavras de Rui Barbosa é compreendida como:

${ }^{60}$ GONÇALVES, Tamara Amoroso; CHAMBOULEYRON, Ingrid Cyfer. Direitos humanos das mulheres: não discriminação, direitos sexuais e direitos reprodutivos. In: IKAWA, Daniela; PIOVESAN, Flávia; FACHIN, Melina Girardi (Coord.). Direitos humanos na ordem contemporânea: proteçấo nacional, regional e global. Curitiba: Juruá, 2010. p. 309. V. 4.

${ }^{61}$ SCANDOLARA, Cláudio. Direito do trabalho e realidade: valor e democracia. Porto Alegre: Livraria do Advogado, 2000. p. 179.

${ }^{62}$ GARAUDY, Roger. La libertad. Trad. Sara Manso. Buenos Aires: Lautaro, 1960. p. 200.

${ }^{63}$ GARAUDY, Roger. La libertad. Trad. Sara Manso. Buenos Aires: Lautaro, 1960. p. 237.

${ }^{64}$ SILVA, José Afonso da. Curso de direito constitucional positivo. 36. ed. São Paulo: Malheiros, 2013. p. 235 . 
"a felicidade está na doçura do bem, distribuído sem ideia de remuneração. Ou, por outra, sob uma fórmula mais precisa, a nossa felicidade consiste no sentimento da felicidade alheia, generosamente criada por um ato nosso". ${ }^{65}$

Ressalta-se que a ONU reconhece a busca da felicidade como um direito humano fundamental, a qual surge como consequência dos direitos fundamentais catalogados no sistema jurídico, ou seja, o direito à felicidade surge como um fortalecimento da democracia. ${ }^{66}$ Por conseguinte, por todos os anos em que as mulheres tiveram sua liberdade de escolha profissional mitigada, a impossibilidade de exercer com liberdade plena e respeito suas atividades profissionais, bem como a imposição do dever ser, ocorreu uma ofensa ao seu livre-arbítrio, bem como uma afronta ao seu direito de ser feliz no trabalho, o qual deveria possuir o direito de escolher.

\section{A PROTEÇÃO DO TRABALHO DA MULHER}

Ao longo do tempo, o direito de proteção à mulher vem evoluindo em decorrência da busca pela sua inserção no mercado de trabalho, como também em consequência do aspecto biológico, visto que a mulher não é dotada da mesma força física que o homem, além da maternidade. Desse modo, faz-se necessário averiguar os sistemas de proteção nos mais diversos âmbitos, partindo do estudo dos direitos humanos à Consolidação das Leis Trabalhistas. Antes de adentrar especificadamente na análise da Carta Magna do Brasil, faz-se essencial comentar alguns aspectos do Código Civil de 1916, visto que o empenho por mudanças deste conjunto de normas indubitavelmente influenciou a Constituição Cidadã de 1988.

O Código de 1916 apresenta grande parte de seus artigos sob uma ótica patriarcal. Pode-se afirmar que o marco inicial para romper a supremacia masculina ocorreu em 1962, com a elaboração do Estatuto da Mulher Casada, permitindo

${ }^{65}$ BARBOSA, Rui. Obras completas de Rui Barbosa. Secretaria da Cultura do Rio de Janeiro, 1991. Disponível em: <http://www.stf.jus.br/bibliotecadigital/ruibarbosa/130357/pdf/130357.pdf>.p. 32. Acesso em: 2 ago. 2016.

${ }^{66}$ BELONI, Lúcia Maria. O direito da mulher e a busca da felicidade no ordenamento brasileiro. In: ERNLUND, Daniela Ballão; MARTINS, Graciela (Org.). Coleção Comissóes: a proteção à mulher no ordenamento jurídico brasileiro. Curitiba: OAB/PR, 2014, p. 121-127. 
que as mulheres casadas exercessem sua liberdade de escolha e sua capacidade plena em sua opçấo de emprego. Ressalta-se que foi no ano de 1974, com o presidente Ernesto Geisel, que o salário-maternidade foi incluído como uma das prestações da Previdência Social, atendendo assim uma grande premência das trabalhadoras. Também na época de Geisel foi sancionada a lei no 6.202, a qual atribui à estudante em estado de gestação o regime de exercícios domiciliares.

Já em 1985 o presidente José Sarney sancionou a Lei no 7.353, a qual criou o Conselho Nacional dos Direitos da Mulher (CNDM), cujo objetivo se traduz em promover políticas que visem a "eliminar a discriminação contra a mulher, assegurando-lhe condiçóes de liberdade e igualdade de direitos, bem como sua plena participação nas atividades políticas, econômicas e culturais do país" ${ }^{67}$ Conforme referido, uma série de decretos e leis, inclusive a Consolidação das Leis Trabalhistas, a qual será tratada de modo mais específico no item subsequente, além das diversas movimentaçóes sociais que ocorreram na época, influenciaram a atual Constituição Federal do Brasil, que priorizou os direitos sociais e essenciais do ser humano.

No que respeita à igualdade de gênero, com a promulgação da Carta Magna de 1988, a proteção dos direitos das mulheres foi elevada, na medida em que este direito à igualdade foi tido como fundamental, haja vista o artigo $3^{\circ}$, IV e $5^{\circ}, \mathrm{I}$, deste dispositivo legal. Também foi por meio da Constituição Cidadã que o trabalho passou a ser entendido como um direito social, tendo como base o artigo 60: "são direitos sociais a educação, a saúde, a alimentação, o trabalho, a moradia, $\mathrm{o}$ transporte, o lazer, a segurança, a previdência social, a proteção à maternidade $\mathrm{e}$ à infância, a assistência aos desamparados, na forma desta Constituição".

Já em relação ao artigo $7^{\circ}$ da Constituição Federal, este salvaguarda especificadamente os direitos do trabalhador, inclusive quanto à licença maternidade e paternidade:

Art. $7^{\circ}$ São direitos dos trabalhadores urbanos e rurais, além de outros que visem à melhoria de sua condição social:

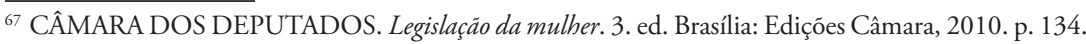


XVIII - licença à gestante, sem prejuízo do emprego e do salário, com a duração de cento e vinte dias;

XIX - licença-paternidade, nos termos fixados em lei. ${ }^{68}$

Tal iniciativa é um grande destaque para a erradicação da discriminação de gênero no âmbito do trabalho, visto que atende a uma das grandes necessidades das mulheres, tanto biológica quanto psicológica, ao julgar pela preocupação materna com a criança, com a Previdência sendo a responsável pelo pagamento desse benefício.

Outro tópico que merece destaque é o artigo 7º, XX da Constituição Federal, o qual garante a "proteção do mercado de trabalho da mulher, mediante incentivos específicos", ${ }^{69}$ que se trata de uma norma de caráter geral e visa a incentivar os tomadores de serviço, por meio de legislação específica, a conceder condiçóes igualitárias de trabalho a todas as pessoas, homens e mulheres, objetivando minimizar a discriminação em relação ao sexo feminino.

Além disso, em se tratando do artigo $7^{\circ}$ da Carta Magna, deve ser analisado o inciso XXX, que visa especificamente a uma proteção ampla contra a "diferença de salários, de exercício de funçôes e de critério de admissão por motivo de sexo, idade, cor ou estado civil". Nesse contexto merece destaque a inclusão da função "de exercício de outras funçóes", que inclui o ato discriminatório, permitindo ao Judiciário e aos legisladores ordinários a criação de instrumentos efetivos para a fiscalização dos atos que venham a atingir este direito. ${ }^{70}$ No ano de 1995 o presidente Fernando Henrique Cardoso decretou a Lei no 9.029, que proíbe a exigência de atestados de gravidez e esterilização, ou qualquer tipologia de discriminação relacionada quando da contratação. ${ }^{71}$

${ }^{68}$ BRASIL. Constituiçẫo Federal. Câmara dos Deputados. Disponível em: <http://www.camara.gov.br/ internet/legislacao/constituicao/CFpdf/Constituicao.pdf>. Acesso em: 17 jul. 2016.

${ }^{69}$ BRASIL. Constituição Federal. Câmara dos Deputados. Disponível em: <http://www.camara.gov.br/ internet/legislacao/constituicao/CFpdf/Constituicao.pdf>. Acesso em: 17 jul. 2016.

${ }^{70}$ MANUS, Pedro Paulo Teixeira. Direito do trabalho. 12. ed. São Paulo: Saraiva, 2009. p. 283.

${ }^{71}$ BRASIL. Lei n. 9.029. Disponível em: <http://www.planalto.gov.br/ccivil_03/LEIS/L9029.HTM>. Acesso em: 23 jul. 2016. 
Parte da doutrina acredita que esta lei causaria mais danos à possibilidade de inserçấo da mulher no mercado de trabalho, sob o argumento de que alguns empregadores se sentiriam em uma situação de insegurança, todavia deve ser levado em conta que se a referida norma deixasse de possuir vigência, seria notória a prática de mais discriminaçôes e criação de requisitos que afunilariam a ingresso da mulher no emprego. Um exemplo recente deste tipo de discriminação foi a exigência de teste de virgindade às mulheres que iriam prestar o concurso para serem bombeiras. Tal fato ocorreu em Brasília, em julho de 2016, e além de ferir o direito à intimidade das concorrentes, vê-se uma desigualdade, posto a inexistência deste pré-requisito aos homens. $^{72}$

A Lei Maria da Penha, visto sua natureza protetiva, garante à mulher vítima de violência, em seu artigo $9^{\circ}, \$ 2^{\circ}$, II, a preservação do vínculo laboral pelo período de seis meses, tanto em âmbito privado quanto no público. Diante disto, há a discussão na doutrina quanto ao pagamento salarial, posto que a referida lei não determina a natureza do licenciamento ou quem deverá realizar o pagamento do salário. A maioria dos doutrinadores, porém, acredita que se trata de uma licença não remunerada, visto ser impossível existir uma interpretação extensiva neste quesito, além de ferir a máxima do Direito do Trabalho: se há labor, é obrigatório existir a contraprestação, todavia se não o há, não existe a obrigação de pagamento salarial. ${ }^{73}$

Apesar deste posicionamento ser muito forte, é claramente contra a intenção do legislador, visto que a vítima, diante da iminência de não receber o salário, indispensável à sua manutenção, acaba por cair na economia informal, pois não pode arranjar outro emprego ou pleitear auxílio-desemprego, ou viver em uma situação degradante, à margem da sociedade, somente existindo. Talvez a solução

${ }^{72}$ MORAIS, Raquel. Concurso de bombeiros exige "teste de virgindade" ou papanicolau no DF. Disponível em: <http://g1.globo.com/distrito-federal/noticia/2016/07/concurso-dos-bombeiros-exige-teste-de-virgindade-ou-papanicolau-no-df.html>. Acesso em: 10 ago. 2016.

${ }^{73}$ DIAS, Maria Berenice. A lei Maria da Penha na Justiça: a efetividade da Lei 11.340/2006 de combate à violência doméstica e familiar contra a mulher. 3. ed. rev. atual e ampl. São Paulo: Revista dos Tribunais, 2013. p. 166. 
mais sensata fosse a proposta de Rogério Sanches Cunha e de Ronaldo Batista Pinto, de que o pagamento seja realizado pelo órgão previdenciário, como acontece na licença-maternidade ou afastamento do empregado por auxílio acidente. ${ }^{74}$

O objetivo central e, porque não, essencial, da CLT, é garantir a proteção do trabalhador em todas as suas formas, inclusive atendendo às particularidades de cada trabalhador, como é o caso do trabalho da mulher e do menor. Partindo deste princípio, antes de adentrar especificadamente nos regulamentos trabalhistas que protegem o trabalho da mulher, faz-se necessário compreender que este cuidado especial possui fundamento tanto pela necessária proteção à maternidade e ao recém-nascido, ou seja, o interesse da sociedade ao amparo familiar, quanto pela diferença muscular advinda do sexo biológico feminino e masculino. ${ }^{75}$ Cabe mencionar que o direito promocional do trabalho da mulher surgiu em uma época em que as medidas proibitivas desta adentrar no mercado de trabalho foram afastadas, ou seja, quando a mulher conquistou sua independência e capacidade plena.

Assim como qualquer pessoa, a mulher pode iniciar a vida laborativa a partir dos 14 anos como aprendiz, contudo o trabalho em horário noturno, bem como em condiçóes perigosas, penosas e/ou insalubres são terminantemente proibidos até o indivíduo completar 18 anos. Devido à peculiar situação da empregada doméstica, essa mereceu uma lei especial, a fim de abarcar todas as suas nuances e respectivas necessidades. Sabe-se que ao longo da História, a empregada doméstica sempre foi vista à margem da sociedade, tanto que várias mulheres começavam a trabalhar nesta profissão desde muito novas, fato que atrapalhava ou muitas vezes findava sua vida escolar. ${ }^{76}$ Assim sendo, a Lei da Empregada Doméstica veio para regulamentar o

${ }^{74}$ CUNHA, Rogério Sanches; PINTO, Ronaldo Batista. Violência doméstica. Lei Maria da Penha comentada artigo por artigo. São Paulo: Ed. Revista dos Tribunais, 2007. p. 54.

${ }^{75}$ NASCIMENTO, Amauri Mascaro. Curso de Direito do Trabalho: história e teoria geral do direito do Trabalho, relações individuais e coletivas do trabalho. 26. ed. São Paulo: Saraiva, 2011. p. 1.002.

${ }^{76}$ MAGANO, Octávio Bueno. Empregado doméstico. Disponível em: <http://www.revistadostribunais. $\mathrm{com} . \mathrm{br} / \mathrm{maf} / \mathrm{app} /$ resultList/document?\&src=rl\&srguid=i0ad81816000001565b3640cbf9145661\&d ocguid=Ic7ca27f03e $5 \mathrm{~d} 11$ e09ce $30000855 \mathrm{dd} 350$ \&hitguid=Ic7ca27f03e 5d11e09ce30000855dd 350 \&spos $=1 \&$ epos $=1 \& \mathrm{td}=1322 \&$ context $=5 \& \mathrm{crumb}$-action $=$ append $\&$ crumb-label $=$ Documento $\&$ isD ocFG=true\&isFromMultiSumm=true\&startChunk=1\&endChunk=1>. Acesso em: 14 maio 2016. 
labor muitas vezes esquecido e quase sempre sem nenhum regramento e descanso, um trabalho exercido por 6 milhóes de mulheres, conforme dados do IBGE no primeiro trimestre de 2015 , fruto da divisão sexual do trabalho. ${ }^{77}$

Quanto à equidade a CLT define em seu artigo 461:

Art. 461 - Sendo idêntica a função, a todo trabalho de igual valor, prestado ao mesmo empregador, na mesma localidade, corresponderá igual salário, sem distinção de sexo, nacionalidade ou idade. $\$ 1^{\circ}$ - Trabalho de igual valor, para os fins deste Capítulo, será o que for feito com igual produtividade e com a mesma perfeição técnica, entre pessoas cuja diferença de tempo de serviço náo for superior a 2 (dois) anos.

$\$ 2^{\circ}$ - Os dispositivos deste artigo não prevalecerão quando o empregador tiver pessoal organizado em quadro de carreira, hipótese em que as promoções deverão obedecer aos critérios de antiguidade e merecimento. $\$ 3^{\circ}$ - No caso do parágrafo anterior, as promoçōes deverão ser feitas alternadamente por merecimento e por antiguidade, dentro de cada categoria profissional.

$\$ 4^{\circ}$ - O trabalhador readaptado em nova função por motivo de deficiência física ou mental atestada pelo órgão competente da Previdência Social não servirá de paradigma para fins de equiparação salarial.

Neste sentido, conclui-se que o trabalho igual é aquele feito com idêntica produtividade e mesma produção técnica. Além disso, para existir a equiparação salarial, leva-se em conta o salário, e não a remuneração, devendo-se preencher os seguintes requisitos: identidade de funçóes; diferença náo superior a 2 anos entre o paradigma e o equiparado; labor prestado na mesma localidade; o paradigma e o equiparado devem ter trabalhado em algum momento juntos.

No que diz respeito à jornada de trabalho, esta será de 8 horas diárias e no máximo de 44 horas semanais, independentemente do sexo biológico, sendo indispensável o intervalo de no mínimo 1 hora e no máximo 2 horas, quando o

77 BIROLI, Flávia. Trabalhadoras domésticas, cidadania e servilidade: o Brasil de "Que horas ela volta?”. Disponível em: <http://grupo-demode.tumblr.com/post/129063917712/trabalhadoras-dom\%C3\%A9sticas-cidadania-e-servilidade>. Acesso em: 14 maio 2016. 
labor realizado for superior a 6 horas contínuas. Ressalta-se que muito se discutiu acerca da constitucionalidade do artigo 384 da CLT, o qual dispóe o intervalo de 15 minutos em caso de prorrogação no horário normal de trabalho.

Ainda ao que se refere à jornada de trabalho da mulher, o artigo 386 da CLT dispóe que quando existir trabalho aos domingos, também deverá existir escala de revezamento quinzenal, com a mesma orientação sendo também aplicada aos feriados. Cabe informar que a instrução não se aplica aos homens, e que tal proteção objetiva a proteção da entidade familiar. Todo o local de trabalho deve fornecer as condiçóes para que o obreiro exerça sua atividade de forma digna. Enfatiza-se que, quando necessária a troca de vestimentas para a realização do trabalho, deve o empregador disponibilizar vestiários com armários individuais e privados às mulheres.

Destaca-se também que, em conformidade com o artigo 390 da CLT, a mulher não pode ser submetida a esforços superiores as suas forças físicas, de modo que é defeso a obreira executar atividades que exijam força muscular superior a 20 quilos para o trabalho contínuo e 25 quilos quando ocasional. ${ }^{78}$ Por sua vez, as normas de proteçáo à maternidade são tidas como imperativas $;{ }^{79}$ assim, mesmo que a trabalhadora quisesse laborar, isto se tornaria ilegal, visto a existência de perigo à saúde do bebê, como também à da mãe.

\section{MEDIDAS DE COMBATE À DESIGUALDADE DE GÊNERO}

Em uma democracia que "reconheça a diversidade e pluralidade da cidadania das mulheres", ${ }^{80}$ a participação feminina no processo de decisão é fundamental, entretanto mesmo considerando os diversos avanços quanto à

\footnotetext{
${ }^{78}$ NASCIMENTO, Amauri Mascaro. Curso de Direito do Trabalho: história e teoria geral do Direito do Trabalho, relações individuais e coletivas do trabalho. 26. ed. São Paulo: Saraiva, 2011. p. 914.

${ }^{79}$ BARROS, Alice Monteiro de. Curso de Direito do Trabalho. 7. ed. São Paulo: LTr. 2011. p. 867.

${ }^{80}$ THOME, Candy Florencio. O princípio da igualdade de gênero e a participação das mulheres nas organizaçōes sindicais de trabalhadores. São Paulo: LTr, 2012. p. 167.
} 
igualdade de gênero, as mulheres ainda ocupam, em sua grande maioria, cargos de menor potencial de decisão, sequela do sistema patriarcal que ainda se faz presente na atualidade. ${ }^{81}$

Assim, segundo Habermas, é essencial a participação efetiva dos cidadãos na democracia, e somente eles, quando envolvidos, poderão lutar pelos seus direitos, e no caso das mulheres, pela igualdade. A teoria de Habermas, apesar de não considerar a divisão sexual do trabalho, é um dos primeiros estudos a propor uma inclusão e uma democracia participativa.

Conforme a juíza do Trabalho Candy Florencio Thome o problema da igualdade de gênero encontra-se nas formas de distribuição do poder, que se materializam nos meios de chegar-se aos recursos materiais, econômicos e até mesmo culturais. Por conseguinte, a maior inserção das mulheres no poder se decisão, por meio de sua participação nas estruturas de poder, acarretaria, possivelmente, um novo posicionamento, "tornando-se as mulheres sujeitos capazes de se posicionar de maneira diferente e de se redefinir". ${ }^{82}$

A função do Estado perante a sociedade, com o decorrer do tempo, modificou-se, sendo que, atualmente, a ordem econômica é descrita como neoliberal, possuindo o Estado o dever de promover e garantir o bem-estar de todos os cidadáos.

É sob este aspecto que o ativismo do Judiciário ganha existência e força de atuação, constituindo um meio de garantir os princípios da Carta Magna. Assim pondera Konrad Hesse:

A força que constitui a essência e a eficácia da Constituição reside na natureza das coisas, impulsionando-a, conduzindo-a e transformando-se, assim, em força ativa. Como demonstrado, daí decorrem os seus limites. Daí resultam

${ }^{81}$ HABERMAS, Jürgen. Era das transiçóes. Trad. Flávio Beno Siebeneichler. Rio de Janeiro: Tempo Brasileiro, 2003. p. 53.a

${ }^{82}$ THOME, Candy Florencio. O princípio da igualdade de gênero e a participação das mulheres nas organizaçōes sindicais de trabalhadores. São Paulo: LTr, 2012. p. 168 
também os pressupostos que permitem à Constituição desenvolver de forma ótima a sua força normativa. Esses pressupostos referem-se tanto ao conteúdo da Constituição quanto à práxis constitucional. ${ }^{83}$

Esclarece-se que o ativismo do Judiciário possui quatro campos de atuaçáo e pensamento, os chamados ativismo contramajoritário, jurisdicional, criativo e remedial. Assim, o primeiro é compreendido como a negativa dos tribunais em aplicar decisóes governamentais, já o segundo consiste em uma maior intervençáo do Judiciário, visando a atuar de modo a suprir a falta de lei ou determinaçóes; por sua vez o criativo consiste em utilizar-se da interpretação das normas jurídicas, objetivando a criação de novos direitos; finalmente, o remedial traduz-se na obrigação do poder Judiciário de criação de políticas públicas e órgãos. ${ }^{84}$

O Direito não é estático, ele deve acompanhar as alteraçóes da sociedade, portanto, mesmo que não exista uma determinada norma para aquela situaçáo excepcional, incumbe ao poder Judiciário dar uma resposta e atender aos anseios da população da melhor maneira. Nesse contexto, diante da desigualdade de gênero e pelos mais diversos modos de violência enfrentados pelas mulheres. é funçáo do Estado garantir a promoção da justiça social, principalmente a eficácia dos direitos fundamentais, não apenas na mera previsão no corpo legislativo.

Nesta perspectiva, sustentam Claudio Rogério Teodoro Oliveira e Tatiana Coutinho Pitta:

Tornar efetiva a proteção normativa existente significa optar pela concretização aos direitos assegurados à mulher em reconhecimento à desigualdade em relação ao homem, que ocasiona a alarmante situação de violência de gênero no

${ }^{83}$ HESSE, Konrad. A força normativa da Constituição. Trad. Gilmar Ferreira Mendes. Porto Alegre: Sergio Antonio Fabris Ed., 1991. p. 20.

${ }^{84}$ CARMONA, Georgia Lage Pereira. A propósito do ativismo judicial: super poder judiciário? Revista Ambito Jurídico.com. Disponível em: <http://www.ambito-juridico.com.br/site/?n_link=revista_artigos_leitura\&artigo_id=11605>. Acesso em: 11 maio 2016. 
país. Trata-se de verdadeira medida de acesso à justiça social para que a mulher seja alçada a um patamar de igualdade perante o homem nas relaçóes sociais e domésticas. ${ }^{85}$

Dessa maneira, contribuindo com o ativismo, as políticas públicas surgem como açôes governamentais, cuja finalidade é atender às necessidades dos cidadãos.

\section{CONSIDERAÇÕES FINAIS}

Após um juízo de valores chega-se à conclusão de que a desigualdade entre gêneros, principalmente em relação às mulheres no mercado de trabalho, faz-se ainda presente no século 21. Isso posto, em um mundo em que se tem como ideal a dignidade da pessoa humana e a igualdade entre os indivíduos, sem qualquer distinção, torna-se fundamental estudar a respeito e buscar soluçóes para esta problematização.

Sabe-se que o sexo biológico é diferente de gênero, posto que o primeiro leva em consideração apenas os fatores biológicos; já o segundo é compreendido como o entendimento que o ser humano possui sobre si mesmo. Assim, no decorrer da História a mulher foi amplamente marginalizada, devendo ser submissa aos homens em qualquer situação. Conforme a ótica patriarcal, as mulheres deveriam corresponder às expectativas masculinas, elas eram educadas para exercer trabalhos domésticos, e foi apenas a partir da Idade Moderna, com o Renascimento, que as mulheres começaram a exigir sua liberdade e autonomia. Foi somente com a Revolução Industrial, no entanto, que a mão de obra feminina foi inserida em grande escala, todavia, não por motivos nobres, como a defesa da igualdade, apenas por ser considerada uma mão de obra barata. No Brasil, até meados do século 20, a mulher não tinha liberdade de escolha profissional, devendo o marido autorizá-la a laborar.

${ }^{85}$ OLIVEIRA, Claudio Rogério Teodoro; PITTA, Tatiana Coutinho. Da (in) dignidade da mulher na sociedade contemporânea e a necessária atuação estatal implemento de justiça social. In: SIQUEIRA, Dirceu Pereira; SILVA, Nilson Tadeu Reis Campos (Org.). Minorias e grupo vulneráveis: reflexóes para uma tutela inclusiva. Birigui: Boreal, 2013. p. 187. 
São estas degradantes situaçôes que moveram vários movimentos e o surgimento do feminismo em prol da igualdade, do respeito, do direito à felicidade e da liberdade também para a mulher. $\mathrm{O}$ ser humano deve ser tratado com dignidade, independentemente de sua cor, raça e religião, de modo que a divisão sexual do trabalho, por motivos inerentes ao culturalismo e pela justificação do sexo biológico, torna-se inadmissível.

Ainda em tempos atuais, contudo, resquícios do patriarcalismo e a discriminação se fazem presentes. As mulheres sofrem preconceitos para conseguir e manter-se em uma determinada profissão, até hoje existe diferença salarial, ainda há a divisão sexual laboral. Em razão destas desonrosas atitudes, foram criadas leis de proteção ao trabalho da mulher, estipulando a licença-maternidade, jornada de trabalho, equidade salarial, a idade e o tempo de contribuição para a mulher conseguir o benefício previdenciário da aposentadoria, entre outras garantias protetivas.

Há, todavia, quem defende a ideia de que a positivaçáo de tais leis resultou em uma maior discriminaçáo da mulher no mercado de trabalho, além de se tratar de um ultraje ao direito à igualdade. Como demonstrado, porém, tal pensamento não deve prevalecer, posto que em um mundo em que não existisse tais normatizaçôes, a mulher indubitavelmente continuaria sendo ainda mais marginalizada e discriminada. De tal modo, a igualdade não deve ser vista em seu aspecto formal, mas sim no material, de modo que sejam respeitadas as condiçóes especiais dos grupos sociais considerados como as minorias, que lutam diariamente por essa mesma igualdade e pela devida efetivação de seus direitos.

Buscando, portanto, a efetividade das leis e dos princípios que regem todo ordenamento, principalmente em relação à mulher, faz-se imprescindível a atuação do Estado por meio do ativismo do Judiciário. Conclui-se, portanto, que, a igualdade de gêneros é um problema de toda a sociedade, que afeta, por conseguinte, não apenas as mulheres, mas também meninas, meninos, homens e idosos. Trata-se de um impedimento da verdadeira aplicação dos direitos humanos, fundamentais e trabalhistas.

\section{REFERÊNCIAS}

ALEXY, Robert. Teoria dos Direitos Fundamentais. Virgílio Afonso da Silva (Trad.). 2. ed. São Paulo: Malheiros, 2008. p. 408. 
BARBOSA, Rui. Obras completas de Rui Barbosa. Secretaria da Cultura do Rio de Janeiro, 1991. Disponível em: <http://www.stf.jus.br/bibliotecadigital/ruibarbosa/130357/ pdf/130357.pdf>. Acesso em: 2 ago. 2016.

BARROS, Alice Monteiro de. Curso de Direito do Trabalho. 7. ed. Sáo Paulo: LTr. 2011. p. 855,867 .

BEAUVOIR, Simone de. O segundo sexo: fatos e mitos. Tradução Sérgio Milliet. 4. ed. São Paulo: Difusão Europeia do Livro, 1970. V. 1.

BELONI, Lúcia Maria. O direito da mulher e a busca da felicidade no ordenamento brasileiro. In: ERNLUND, Daniela Ballão; MARTINS, Graciela (Org.). Coleção Comissōes: a proteção à mulher no ordenamento jurídico brasileiro. Curitiba: OAB/PR, 2014, p. 121-127.

BIROLI, Flávia. Trabalhadoras domésticas, cidadania e servilidade: o Brasil de "Que horas ela volta?”. Disponível em: <http://grupo-demode.tumblr.com/post/129063917712/ trabalhadoras-dom\%C3\%A9sticas-cidadania-e-servilidade>. Acesso em: 14 maio 2016.

BOURDIEU, Pierre. A dominação masculina. Trad. Maria Helena Kuhner. Rio de Janeiro: Bertrand Brasil,1999.

BRASIL. Constituiçâo Federal. Câmara dos Deputados. Disponível em: <http://www.camara. gov.br/internet/legislacao/constituicao/CFpdf/Constituicao.pdf>. Acesso em: 17 jul. 2016.

BRASIL. Lei n. 11.340. Disponível em: <http:/www.planalto.gov.br/ccivil_03/_ato20042006/2006/lei/l11340.htm>. Acesso em: 3 ago. 2016.

.Lei n. 9.029. Disponível em: <http://www.planalto.gov.br/ccivil_03/LEIS/L9029. HTM>. Acesso em: 23 jul. 2016.

Observatório Brasil da igualdade de gênero. Brasil cai para $82^{\circ}$ em desigualdade de gênero, aponta relatório. Disponível em: <http://www.observatoriodegenero.gov.br/ $\mathrm{menu} /$ noticias/brasil-cai-para-82o-em-desigualdade-de-genero-aponta-relatorio $>$. Acesso em: 17 jul. 2015.

BRUSCHINI, Maria Cristina A.; ROSEMBERG, Fúlvia. A mulher e o trabalho. In: BRUSCHINI, Maria Cristina A.; ROSEMBERG, Fúlvia (Org.). Trabalhadoras do Brasil. São Paulo: Brasiliense; Fundação Carlos Chagas, 1982.

BULOS, Uadi Lammêgo. Curso de Direito Constitucional. 8. ed. rev. e atual. São Paulo: Saraiva, 2014.

CÂMARA DOS DEPUTADOS. Legislação da mulher. 3. ed. Brasília: Edições Câmara, 2010. p. 134. 
CARMONA, Georgia Lage Pereira. A propósito do ativismo judicial: super poder judiciário? Revista Âmbito Jurídico.com. Disponível em: <http://www.ambito-juridico.com.br/ site/?n_link=revista_artigos_leitura\&artigo_id=11605>. Acesso em: 11 maio 2016.

CARNEIRO, Adriana Jacob. Gênero e mídia: a cobertura do Dia Internacional da Mulher. 2011. 200 f. Dissertação (Mestrado) - Universidade Federal da Bahia, Faculdade de Comunicação, Salvador, 2011. Disponível em: <https://repositorio.ufba.br/ri/bitstream/ri/8679/1/ Adriana\%20Jacob\%20Carneiro.pdf>. Acesso em: 25 jun. 2016.

CAVALCANTI, Christiane Villela. A moda de luxo e a mulher em uma capital brasileira. Dissertação (Mestrado) - Programa de Pós-Graduação em Administração, Pontifícia Universidade Católica de Minas Gerais, Belo Horizonte, 2013. Disponível em: <http://www. biblioteca.pucminas.br/teses/Administracao_CavalcantiCV_1.pdf>. Acesso em: 5 fev. 2016.

CONFEDERAÇÃO NACIONAL DA INDÚSTRIA (CNI). Retratos da Sociedade Brasileira, n. 30. Rotatividade no mercado de trabalho. Mar. 2016. Dados estratificados. Disponível em: <http://www.portaldaindustria.com.br/estatisticas/rsb-30-rotatividade/>. Acesso em: 4 maio 2017.

CORREIO BRAZILIENSE. Mulheres só receberão o mesmo salário que homens em 2086, diz OIT. Brasília, 6 mar. 2015. Disponível em: <http://www.correiobraziliense.com.br/app/ noticia/mundo/2015/03/06/interna_mundo,474329/mulheres-so-receberao-mesmo-salario-que-homens-em-2086-oit.shtml>. Acesso em: 17 jul. 2015.

CUNHA, Rogério Sanches; PINTO, Ronaldo Batista. Violência doméstica. Lei Maria da Penha comentada artigo por artigo. São Paulo: Ed. Revista dos Tribunais, 2007.

DAHL, Tove Stang. O Direito das mulheres: uma introdução à teoria do direito feminista. Lisboa: Fundação Calouste Gulbenkian, 1993. p. 14, 41.

DIAS, José Francisco de Assis. Direitos humanos: fundamentação onto-teleológica dos direitos humanos. Maringá: Unicorpore, 2005. p. 55.

DIAS, Maria Berenice. A lei Maria da Penha na Justiça: a efetividade da Lei 11.340/2006 de combate à violência doméstica e familiar contra a mulher. 3. ed. rev. atual e ampl. São Paulo: Revista dos Tribunais, 2013.

FAUSTO-STERLING, Anne. Dualismos em duelo. Cadernos Pagu, Campinas, n. 17-18, p. 9-79, 2002. Disponível em: <http://www.scielo.br/scielo.php?script=sci_arttext\&pid=S0104$-83332002000100002 \& \operatorname{lng}=$ en $\&$ nrm=iso $>$. Acesso em: 26 jun. 2016.

FAZOLI, Carlos Eduardo de Freitas; SILVA, Fernando Henrique Rugno da. A tutela interdital: um instrumento para a efetivação dos direitos fundamentais. Revista Direitos Sociais e Políticas Públicas - Unifafibe, v. 2, n. 2, 2014. 
FUNDAMENTAL. In: Dicionário Michaelis. Disponível em: <http:http://michaelis.uol. com.br/moderno/portugues/index.php?lingua=portugues-portugues\&palavra=fundament al>. Acesso em: 27 mar. 2016.

GARAUDY, Roger. La libertad. Trad. Sara Manso. Buenos Aires: Lautaro, 1960.

GONÇALVES, Tamara Amoroso; CHAMBOULEYRON, Ingrid Cyfer. Direitos Humanos das Mulheres: Não discriminação, direitos sexuais e direitos reprodutivos. In: IKAWA, Daniela; PIOVESAN, Flávia; FACHIN, Melina Girardi (Coord.). Direitos Humanos na Ordem Contemporânea: proteção nacional, regional e global. Curitiba: Juruá, 2010. V. 4.

HABERMAS, Jürgen. Era das transiçōes. Trad. Flávio Beno Siebeneichler. Rio de Janeiro: Tempo Brasileiro, 2003. p. 53.

HESSE, Konrad. A força normativa da Constituição. Trad. Gilmar Ferreira Mendes. Porto Alegre: Sergio Antonio Fabris Ed., 1991.

HIRATA, Helena; SEGNINI, Liliana (Org.). Organização, trabalho e gênero. São Paulo: Senac São Paulo, 2007.

JESUS, Jaqueline Gomes de. Orientações sobre a população transgênero: conceitos e termos. Brasília: Autor, 2012. Disponível em: <https://www.sertao.ufg.br/up/16/o/ ORIENTA\%C3\%87\%C3\%95ES_SOBRE_IDENTIDADE_DE_G\%C3\%8ANERO_ CONCEITOS_E_TERMOS_-_2\%C2\%AA_Edi\%C3\%A7\%C3\%A3o.pdf?1355331649>. Acesso em: 25 jun. 2016.

KERGOAT, Danièle. Divisão sexual do trabalho e relaçôes sociais de sexo. Tradução Miriam Nobre. ago. 2003. Disponível em: <http://poligen.polignu.org/sites/poligen.polignu.org/ files/adivisaosexualdotrabalho_0.pdf>. Acesso em: 28 jun. 2016. p. 1.

LAQUEUR, 1990, p. 151 apud NICHOLSON, Linda. Interpretando o gênero. Tradução Luiz Felipe Guimarães Soares. Revista Estudos Feministas, Florianópolis, v. 8, n. 2, p. 21, 2000. Disponível em: <https://periodicos.ufsc.br/index.php/ref/article/view/11917>. Acesso em: 26 jun. 2016.

LIMA, Paulo Roberto de Oliveira. Isonomia entre os Sexos no Sistema Jurídico Nacional. São Paulo: Revista dos Tribunais, 1993.

LUCENA, Mariana Barrêto Nóbrega de. Os debates do movimento feminista: do movimento sufragista ao feminismo multicultural. Disponível em: <http://www.ufpb.br/evento/lti/ocs/ index.php/17redor/17redor/paper/view/100/49>. p. 6. Acesso em: 24 maio 2016.

MAGANO, Octávio Bueno. Empregado doméstico. Disponível em: <http://www.revistadostribunais.com.br/maf/app/resultList/document? \&src=rl\&srguid=i0ad81816000001 565b3640cbf9145661\&docguid=Ic7ca27f03e5d11e09ce30000855dd350\&hitguid=Ic7 
ca27f03e $5 \mathrm{~d} 11$ e09ce30000855dd350\&spos = 1 \&epos $=1 \& \mathrm{td}=1322 \&$ context $=5$ \& crumb-action=append\&crumb-label=Documento\&isDocFG=true\&isFromMultiSumm=true\&s tartChunk=1\&endChunk=1>. Acesso em: 14 maio 2016.

MANUS, Pedro Paulo Teixeira. Direito do trabalho. 12. ed. São Paulo: Saraiva, 2009.

MARTINES, Temistocle. Diritto costituzionale. 11. ed. Milano: Giuffrè, 2005. p. 527. Levar todos para ref.

MORAES, Alexandre de. Direito constitucional. 11. ed. São Paulo: Atlas, 2002.

MORAIS, Raquel. Concurso de bombeiros exige "teste de virgindade" ou papanicolau no DF. Disponível em: <http://g1.globo.com/distrito-federal/noticia/2016/07/concurso-dos-bombeiros-exige-teste-de-virgindade-ou-papanicolau-no-df.html>. Acesso em: 10 ago. 2016.

NASCIMENTO, Amauri Mascaro. Curso de Direito do Trabalho: história e teoria geral do Direito do Trabalho, relaçóes individuais e coletivas do trabalho. 26. ed. São Paulo: Saraiva, 2011. p. 908, 914, 1.002 .

NICHOLSON, Linda. Interpretando o gênero. Tradução Luiz Felipe Guimarães Soares. Revista Estudos Feministas, Florianópolis, v. 8, n. 2, 2000. Disponível em: <https://periodicos. ufsc.br/index.php/ref/article/view/11917>. Acesso em: 26 jun. 2016.

OLIVEIRA, Claudio Rogério Teodoro; PITTA, Tatiana Coutinho. Da (in) dignidade da mulher na sociedade contemporânea e a necessária atuação estatal no implemento de justiça social. In: SIQUEIRA, Dirceu Pereira; SILVA, Nilson Tadeu Reis Campos (Org.). Minorias e grupo vulneráveis: reflexóes para uma tutela inclusiva. Birigui: Boreal, 2013.

ORGANIZAÇÃO INTERNACIONAL DO TRABALHO (OIT). Promovendo o trabalho decente. Disponível em: <http://www.oitbrasil.org.br/convention>. Acesso em: 25 jun. 2016.

PACKEL, Amanda K.; RHODE, Deborah. Diversity on Corporate Boards: How Much Difference Does Difference Make? Delaware Journal of Corporate Law (DJCL), vol. 39, n. 2, p. 377-426, 2014. Disponível em: <https://ssrn.com/abstract=1685615> e <http://dx.doi. org/10.2139/ssrn.1685615>.

PIOVESAN, Flávia; SARMENTO, Daniel. Igualdade, diferença e direitos humanos. Rio de Janeiro: Lumen Juris, 2008, p.138.

RABENHORST, Eduardo Ramalho. Feminismo e Direito. In: Revista do Núcleo de Estudos e Pesquisas em Gênero e Direito, João Pessoa: UFPB, v. 1, n. 1, 2010, nota 1.

RAMPTON, Martha. The Three waves of feminism. Pacific University Center for Gender Equity, Gender and Sexuality Studies Minor, out/2014. Disponível em: <https://www. pacificu.edu/about-us/news-events/four-waves-feminism>. 
ROCHA, Patrícia. Mulheres sob todas as luzes: a emancipação feminina e os últimos dias do patriarcado. Belo Horizonte: Ed. Leitura, 2009.

ROMANZOTI, Natasha. Sociedade em que as mulheres mandam podem nos ensinar muitas coisas. Disponível em: <http://hypescience.com/sociedades-em-que-as-mulheres-mandam/>. Acesso em: 2 ago. 2016.

SAFFIOTI, Heleith Iara Bongiovani. Gênero, patriarcado, violência. São Paulo: Fundação Perseu Abramo, 2004.

SANTO AGOSTINHO apud BEAUVOIR, Simone de. O segundo sexo: fatos e mitos. Tradução Sérgio Milliet. 4. ed. São Paulo: Difusão Europeia do Livro, 1970. p. 73. V. 1.

SANTOS, Boaventura de Sousa. Pela mão de Alice: o social e o político na pós-modernidade. 10. ed. São Paulo: Cortez, 2005.

SCANDOLARA, Cláudio. Direito do trabalho e realidade: valor e democracia. Porto Alegre: Livraria do Advogado, 2000.

SILVA, José Afonso da. Curso de direito constitucional positivo. 36. ed. São Paulo: Malheiros, 2013.

STEARN, Peter N. História das relações de gênero. 2. ed. Tradução Mirna Pinsky. São Paulo: Contexto, 2015. p. 23.

SULLEROT, Evelyne. História y sociologia de trabajo femenino. Tradução Bustamante Ortiz. Barcelona: Ediciones, 1970.

TAVARES, André Ramos. Curso de direito constitucional. 11. ed. São Paulo: Saraiva, 2013. p. 442.

THOME, Candy Florencio. O princípio da igualdade de gênero e a participaçāo das mulheres nas organizaçôes sindicais de trabalhadores. Sáo Paulo: LTr, 2012.

URIARTE, Oscar Ermida. Prefácio. In: LIMA, Firmindo Alves. Teoria da discriminação nas relaçóes de trabalho. Rio de Janeiro: Elsevier, 2011. p. 15.

WEBER, Max. Economia e sociedade: fundamentos da sociologia compreensiva. Brasília: UnB, 2000.. 